a small lake, about three-quarters of a mile in width, out of which flowed the stream which joins the Panja branch of the Oxus at Bozai-Gumbaz."

After this Captain Younghusband made his way down to Kashmir.

\section{THE INSTITUTION OF MECHANICAL} ENGINEERS.

$\mathrm{O}^{\mathrm{N}}$ Thursday and Friday evenings of last week, the $4^{\text {th }}$ and 5 th inst., the Institution of Mechanical Engineers held ir forty-fifth annual general meeting in the theatre of the Institution of Civil Engineers, lent for the purpose by the Council of the latter Society, according to custom.

The first business was the reading of the annual report of the Council, from which it appears that the Institution continues to prosper, both in regard to finances and membership. The accumulated surplus now amounts to about $£ 36,000$, and is increasing at the ate of over $£ 2000$ per annum. At the end of last year the number of names of all classes on the roll of membership amounted to 2077 , a net gain of 134 on the previous year.

The following two papers were read and discussed :-

(I) Notes on mechanical features of the Liverpool Waterworks, and on the supply of power by pressure from the public mains, and by other means, by Joseph Parry, water engineer, Liverpool.

(2) On the disposal and utilization of blast-furnace slag, by William Hawdon, of Middlesborougb.

The first paper was chiefly valuable as recording an attempt of the Liverpool Corporation, who control the water supply of the city, to establish a system of power distribution by means of the ordinary mains. The Liverpool water supply is chiefly interesting at the present time from the fact that the Vyrnwy works and connections are all but complete. When this system is in operation the Liverpool mains will carry a pressure of water obtained by a natural head, due to the source of supply being in the higher land of North Wales. At present there are in active duty, in connection with the Liverpool Water-works, some fine examples of veteran pumping-engines. There is a Cornish engine and boiler erected at the Windsor station in $\mathbf{1} 840$; a crank engine made in 1837 ; and a fine old Cornish pumping-engine and boiler made by the celebrated firm of Harvey and Co., of Hayle, in Cornwall. The cylinder of the latter is 50 inches in diameter, with a 9 -foot stroke, and is steamjacketed. The pump is $17 \frac{1}{4}$ inches in diameter by 8 feet 9 inches stroke. The average boiler pressure is 35 pounds per square inch. Since this engine began its career it has lifted $\mathbf{I} 8,854$ million foot-tons of water. By a recent trial its duty was found to be 55.7 millions of foot-pounds per cwt. of coal. The indicated horse-power is about 86. The figures serve to show that, in spite of higher pressures and quicker piston-speeds, now so much talked of, not so much advance has been made in the economy of big engines as one might be led to suppose from the efforts that are made to introduce three and four stage compounding, and the virtues that are attributed to it. The average rate of water supply of Liverpool per head per day is about $24 \frac{1}{2}$ gallons, and the water is distributed on the constant service system. Mr. P. Howden's figures as to cost of various systems of power supply are valuable, but they would have been rendered still more so had he taken the further trouble of introducing a more crderly system of classification, and had he given, in one or two instances, fuller information as to the elements upon which he had based his calculations. However, we must not look our gift horse too curiously in the mouth, and any information on one of the great problems of the hourcommon power supply from central stations-is to be made the most of at present. No doubt civilization has lagged behind somewhat in this respect. Power "laid on" in our houses might be as much a matter of course as the bringing of gas and water to us by automatic means; and doubtless this would do something towards solving that other great problem of the hour -and most other hours-the domestic servant problem. At present nearly all large buildings in London, and still more so in America, have a fairly large power installation in their basements. The number of steam boilers that are hidden away among the foundations of large hotels, clubs, and stacks of offices would surprise many people not familiar with these matters. All this involves some waste of room and some waste of energy. In New York a few months ago an effort was made to solve the problem of power distribution by generating steam in a gigantic battery of boilers in one central station, and running the steam pipes all over the city; so that one had only to open a valve and the steam engine could be started forthwith. The scheme was not altogether a success. After a very short time New Yorkers were disagreeably surprised by artificial geysers and mud fountains springing up in the middle of some of the most frequented thoroughfares. A great outcry was raised, and for some time it seemed as if popular indignation would compel the company to stop their work. We believe, however, that there have been improvements lately, but it does not seem probable that steam, conveyed in pipes, will be the means by which power distribution will find its solution in England. Compressed air possesses strong advocates, and in Paris the Popp system, originally devised simply for working clocks from a common centre, has proved a success. In England, however, we have the recent failure at Birmingham, where much money has been spent and many disappointments caused by an endeavour to supply compressed air for power purposes in the city, which, perhaps, of all others in the world, offers the most promising field for such an enterprise. The Hydraulic Power Company has proved a success in London, and its ramifications extend over a wider area than most people imagine; but here, we think, the enterprise finds by far its greatest outlet simply in working elevators and lifts. The gas companies are the largest distributors of power. Perhaps the keenest struggle for lighting and supplying domestic power will be between gas and electricity. The latter has the advantage, from a power point of view, that the motor is clean, compact, odourless, and comparatively noiseless. There is no denying that the gas-engine is not a pleasant neighbour. It is also difficult to start, and requires a large water supply; it smells badly, and makes a noise. On the other hand, it is far cheaper than electricity. Mr. Parry, in his paper, gives an instance of a gas-engine working a hoist in Liverpool at the cost of one-third of a penny per indicated horse-power per hour, and this we should not class as a low figure by any means; whilst Sir James Douglass stated that the charge made for the same unit of power by the Liverpool Electric Supply Company was $5 d$. per hour. There is one other source of power which is yet in its extreme infancy, but of which, we think, much will be heard before long. That is the oil-engine. It cannot be brought into the category of power distribution, however, as each motor of this kind must work on its own bottom. For country districts and isolated positions, at any rate, it offers great promise, and will assuredly take a prominent position when the mechanical details have been brought to a higher state of perfection. The chief interest in Mr. Parry's paper centres in the tables giving figures as to cost. These may be briefly summed up in the statement that when water at high pressure ( 700 pounds) can be bought for $5 s$. per thousand gallons, water power at average domestic pressure (50 to 70 pounds) cannot compete with it. Whether high pressure water will be able to beat electricity and gas is a problem the solution of which is hidden in the future ; and doubtless all the systems mentioned have advantages peculiar to them which would give each in turn the preference under given conditions. Hydraulic distribution has a great point in its favour when the exhaustwater can be used for other purposes.

The disposal of blast-furnace slag would not appear a very interesting question to the uninitiated, but it is really a very important matter. In Great Britain the iron-masters of the country produce annually $12,000,000$ tons of this all but unused material. It is the refuse of iron-smelting, and it may be added that this annual supply of waste matter absorbs, and radiates uselessly into space, heat units which require for their production 653,000 tons of coal. A very small part of this slag is applied to any useful end ; by far the greater quantity of it simply cumbers the ground, or necessitates the spending of large sums in carrying it out to sea. Of course, iron cannot be made without producing slag. To smelt the ore limestone has to be used in order to separate the various impurities with which it is blended. In this way the slag is produced, and the purer metal is obtained. Mr. Hawdon has devised a machine by which he claims to have facilitated the removal and utilization of the slag. In general principle it is not altogether novel, but it possesses some features which, its inventor claims, renuer its working a success, whereas failure has hitherto accompanied such efforts. In the blast furnace the molten slag separates from molten

NO. I I 63 , VOL. 45] 
iron in consequence of the difference in specific gravity of the two. When the furnace is tapped, the iron runs off to the pigbed to be cast into the well-known form. The slag is usually run into boxes, which are mounted on wheels. The passion for bigness which in the present day characterizes nearly all engineering operations of this nature, has extended to slag handling, so that a box will sometimes hold as much as four tons of slag. When the mass is sufficiently cool to stand alone the sides of the mould are lifted off by a crane, and the bogie is drawn away to the "tip," or " slag mountain," by a locomotive. As the land covered by the "tip" is often very valuable, in some localities being worth as much as $f_{1} 1000$ per acre, it is desirable for this reason alone that the slag should be dealt with in some other way. When the iron-works have a sea outlet, the slag is often taken away in vessels constructed for the purpose, and dropped in deep water. The difficulty here is that the big lumps, or "slag-balls," are difficult to handle. To lower them gently into the barge is too costly, and if they are shot in they are likely to start the rivetting. Hand-breaking was, therefore, had recourse to-a tedious and costly process. In order to overcome this difficulty, an ingenious plan, known as the dry core ystem, has been devised. A hollow iron casting was placed so that the slag would flow round it when run in the mould. This was done so that the slag in cooling would contract round the casting and break up into pieces small enough to be tipped into the barge without injury to the plates and rivetting. $\mathrm{Mr}$. Hawdon has not found this method to be successful; but it is stated that others have followed the plan with advantage. In America a method known as "slopping" is used, and undoubtedly with success. The molten slag is run on to a surface, and a large but comparatively thin cake is so obtained. When this layer is sufficiently cool, another is formed above it, and then other layers, so that the whole forms a stratified mass, wilh planes of demarcation between. Such a body is broken up with comparative ease. Sometimes the slag is taken away in the molten state in "boats" which are simply tanks on. wheels. It is then poured away, leaving a problem for the engineers, and perhaps the geologists, of future generations to solve. There have been other methods of dealing with slag, but these we have not space to describe. Mr. David Joy, a well-known mechanical engineer, took the matter up about twenty years ago, and spent a year or two upon the problem. Some of the devices he originated were extremely ingenious, but for reasons of a commercial nature, his efforts were not continued. There are some uses for furnace slag. It is made into bricks, it is drawn into slag-wool, it is made into cement, and is broken up for ballasting railways, pitching streams, or, when made into concrete, for harbour and breakwater works. In spite of these uses, the great bulk of the $12,000,000$ tons produced each year has to be tipped to waste, and the disposal of this useless by-product is no small part of the iron-master's expense in running his works. It is to aid this that the apparatus before referred to has been devised by Mr. Hawdon. It consists mainly of two large pulleys, over which there runs an endless chain or a metal belt. The pulleys are mounted on horizontal shafts, parallel to each other, and placed in the same horizontal plane. The pulleys are driven by a steam-engine, and the chain is made to travel in this way. The latter is composed of solid bar links, joined by pins, and on it is mounted a continuous series of shallow pans or trays. At one end of the apparatus the stream of molten slag is directed into the pans, and, as the chain is moving continuously, each pan carries off a part of the material. The pans overhang, so that the metal will not spill on to the links. Between the two pulleys there is placed a large flat tank filled with water, and this is so arranged that the upper part of the endless travelling chain or belt dips into the water, the sag of the belt being sufficient for the purpose. There are guide rollers, but these are details which may be neglected in our explanation of principles. The slag flows into the trays just before they dip into the water, so that the molten metal is at once rapidly cooled. This has the effect of cracking the pieces so much that when they fall out of the trays-which they naturally do when the belt turns over the further pulley-into the barge or waggon, they are broken into convenient sized fragments. Mr. Hawdon claims that by this system a very large saving is effected in transporting slag, and a naterial of some commercial value is obtained, the pieces being of suitable size for railway ballast or concrete mixing. From what we hear of the apparatus it appears to do its work well so far.

The summer meeting of the Institution will be held this year at Portsmouth, on fuly 26 and three following days. NO. I I 63 , VOL. 45]

\section{THE ELECTRICAL EXHIBITION.}

$\mathrm{O}$ Saturday evening last the Lord Mayor and the Lady Mayoress, accompanied by Mr. Sheriff Tyler, Mr. Sheriff Foster, Sir John Monckton, and many others, went to the Crystal Palace to inspect the Electrical Exhibition. After their walk round, which lasted about an hour and a half, the visitors were entertained at dinner in the large saloon off the south transept. Among the company were the Attorney-General, Sir Robert Rawlinson, Sir Frederick Abel, F.R.S., Prof. W. E. Ayrton, F.R.S., Major-General Webber, Prof. W. Crookes, F.R.S., Mr. Tesla, Mr. W. H. Preece, F.R.S., Sir James N. Douglass, F.R.S., Major-General Festing, F.R.S., Dr. Hopkinson, F.R.S., Mr. A. Siemens, Prof. Kennedy, Prof. Forbes, Prof. Robinson, Prof. Perry, Prof. Hughes, and Prof. Silvanus Thompson, F.R.S. In the unavoidable absence of the Chairman of the Crystal Palace Company, the Hon. D. J. Monson, the chair was taken by the Deputy-Chairman, Mr. G. 'I. Rait. After the usual loyal toasts, the Lord Mayor proposed "Success to the Exhibition." In doing so he said there was sufficient evidence to warrant him in predicting that the Exhibition would prove a very great success. He recollected how, ten years ago, the electric light occupied the minds of many people, and how at that time the light had what proved to be a very bad start. The light was then undertaken more as a speculation. This checked for a time electrical enterprise, though, in his opinion, it had done no great or permanent harm. He admitted, with some degree of shame, that in the City of London they had been very slow to move in the matter. It was possible that they might have hesitated to commit themselves to some appliance that might have been changed on the morrow. They were, however, in favour of the electric light, and the City had been handed over to the new lighting, which in a short time would be an accomplished fact.

Dr. Hopkinson, in giving "Electric Science and Industry," remarked that the reaction between these two had been very intimate.

Prof. Ayrton, President of the Institute of Electrical Engineers, who responded, said that it was impossible to imagine what progress would be made in electricity in another ten years. At present two conductors were necessary for every electric tramcar (laughter). They had anticipated his joke (renewed laughter). Une conductor took the current, while the other took the current coin (laughter). It might be that in ten years street lamps would be no longer necessary, as vacuum tubes would be used for walking-sticks (laughter). The smoke plague and fog would no longer trouble $\mathrm{us}$, for there would be no coal fires when we could bask in the rays of the electric field, repose in the genial warmth of an equipotential surface, and put our feet on a fender composed of horizontal lines of force (loud laughter). One suggestion he would make--that the electric light might be introduced into that room, for the warmth they had borne during the dinner had been surpassed only by the warmth of their reception by the Directors of the Crystal Palace (laughter).

Mr. R. E. Crompton, President of the Electrical Section of the London Chamber of Commerce, also responded.

Mr. E. Clark proposed "The Health of the Honorary Council and Committees of the Exhibition."

Sir F. Abel, in responding, declared that we were on the threshold of great advances in our knowledge of electricity and its applications.

Mr. W. H. Preece also responded, and congratulated the promoters of the Exhibition upon the fact that they had brought to bear upon the present position of electrical science a fierce and an impartial criticism.

Mr. Tesla acknowledged some compliments paid to him in the course of the evening.

Sir James Douglass gave "The Crystal Palace Company," and the Chairman responded.

\section{UNIVERSITY AND EDUCATIONAL INTELLIGENCE.}

CAmbridge.-Mr. J. J. Lister, of St. John's College; late Assistant Superintendent of the Museum of Zoology, has been appointed Demonstrator in Animal Morphology, iu place of Mr. S. F. Harmer.

Mr. Alexander Scott, of Trinity College, has been appointer 